\title{
$\mathrm{AFM}$ 을 이용한 스트렙타비딘-바이오틴 단백질 복합체의 흡착 분석
}

\author{
박지은 · 김동선* · 최호진* - 신장규** 김판겸** · 임근배**
}

\section{Absorption analysis of streptavidin-biotin complexes using AFM}

\author{
Jee-Eun Park, Dong-Sun Kim*, Ho-Jin Choi*, Jang-Kyoo Shin*", \\ Pan Kyeom Kim**, and Geunbae Lim**
}

\begin{abstract}
Atomic force microscope (AFM) has become a common tool for the structural and physical studies of biological macromolecules, mainly because it provides the ability to perform experiments with samples in a buffer solution. In this study, structure of proteins and nucleic acids has been studied in their physiological environment that allows native intermolecular complexes to be formed. $\mathrm{Cr}$ and $\mathrm{Au}$ were deposited on $\mathrm{p}-\mathrm{Si}(100)$ substrate by thermal evaporation method in sequence with the thickness of $200 \AA$ and $500 \AA$, respectively, since $A u$ is adequate for immobilizing biomolecules by forming a self-assembled monolayer (SAM) with semiconductor-based biosensors. The SAM, streptavidin and biotin interacted each other with their specific binding energy and their adsorption was analyzed using the Bio-AFM both in a solution and under air environment. A silicon nitride tip was used as a contact tip of Bio-AFM measurement in a solution and an antimony doped silicon tip as a tapping tip under air environment. Actual morphology could also be obtained by 3-dimensional AFM images. The length and agglomerate size of biomolecules was measured in stages. Furthermore, $\mathrm{R}_{\mathrm{a}}$ (average of surface roughness) and $\mathrm{R}_{\mathrm{ms}}$ (mean square of surface roughness) and surface density for the adsorbed surface were also calculated from the AFM image.
\end{abstract}

Key Words : AFM, self-assembled monolayer, streptavidin-biotin protein complexes

\section{1. 서 론}

최근 인간의 유전정보가 밝혀지면서 "human genomics"시대가 도래되고, 단백질의 구조 및 수용체로서의 역할이 밝혀지면서 작은 유기 분자들과 단백질 수용체 상호간의 작용이 주목을 받기 시작하였다 ${ }^{[1]}$. 이와 더불 어, 유전정보가 밝혀지면서 생명현상에 있어서 가장 필 수적인 유기물인 단백질이 생체 내에서 형태의 유지, 분자의 수송, 완충작용, 물질대사의 조절, 방어 등과 같 은 광범위한 역할을 수행하고 있으며 질병과도 직접적 인 관련이 있는 것이 보고되고 있다[2]. 단백질 기능 분

겅북대학표 센서 및 디스풀레이공학과 (Department of Sensor and Display Engineering, Kyungpook National University)

*경북대학교 전자전기컴퓨터학부 (School of Electrical Engineering and Computer Science, Kyungpook National University)

**포항공과대학교. 기계공학과 (Department of Mechanical Engineering Pohang University of Science and Technology)

'Corresponding author: jkshin@ee.knu.ac.kr

(Received : January 31, 2006, Accepted : February 20, 2006)
석 및 네트워크 분석으로 얻어진 자료를 바탕으로 고 전적인 방법으로 불가능하였던 질병에 대한 치료 및 예방법을 개발하려는 연구는 생명과학, 보건 및 의료 분야 등에서의 주된 과제로 부각되고 있으며, 대부분의 질병이 유전자 수준이 아닌 단백질 수준에서 유발됨으 로 인해 특정 단백질이나 리간드(ligand)와 특이적으로 상호 작용하는 생체분자의 기능과 역할을 밝히는 연구 가 활발히 진행되고 있다. 결과적으로 단백질은 생명현 상을 표현하는 최종 매개체이며 유전자가 가진 정보보 다 많은 양의 정보를 표현할 수 있으므로 이에 대한 기 능의 분석과 질병 진단을 위한 단백질의 검출이 중요 한 연구 분야로 자리매김하고 있다.

단백질 분석 방법은 DNA 염기서열 분석방법과 유 사한 규명방빕을 가지고 있으며 질량 분석법(mass spectrometry), 광 분석법(optical measurement), 전기 화학적 분석법(electrochemistry measurement) 등이 사 용되고 있다|3-5! 현재 광 분석법이 주류를 이루고 있으 나 이 방법은 형광물질과 고비용의 스캐너 장비를 사 
용해야 하고, 휴대가 어려운 점 등의 문제가 있다. 원 자 힘 현미경(atomic force microscope : AFM)은 생체 분자의 시료 분석 및 영상 측정이 가능하고, 시료의 전 처리가 거의 필요 없으며 나노미터 크기의 시료까지 측정 $(25 \sim 10,000,000$ 배 $)$ 이 가능하여 광학현미경과 동시 에 사용 시에 광학현미경의 제반 특성을 모두 활용하 여 생체분자 분석 기술의 여러 가지 장점을 극대화 할 수 있다 ${ }^{[6]}$. 단백질을 검출하고 분석하기 위한 여러 가 지 방법들 중에서 스트렙타비딘, 바이오틴의 높은 친화 럭과 자기조립단분자막(self-assembled monolayer : $\mathrm{SAM})$ 의 화학적 결합의 튼튼함은 단백질 뿐만 아니라 여러 가지 생체분자의 검출을 위해 다루기 쉽고 유동 적인 기반을 제공한다는 점에서 널리 사용되고 있다 ${ }^{[1]}$. 따라서 이를 이용하면 어떤 바이오틴 위에 붙을 다른 물질들도 표면 위에 고정시킬 수 있으며, 다양한 생체 물질을 붙일 수 있는 장점이 있다. 실제로 바이오틴과 결합된 Anti-HIV p24-ab-biotin을 이용하여 HIV 질병 진단을 하고 있으며, 여러 가지 항원, 항체반응 및 단 백질관련 연구에 사용되고 있다. 이러한 장점들을 이용 하여 본 연구에서는 바이오센서의 적용을 위해 스트렙 타비딘과 바이오틴 단백질 복합체의 결합 반응을 $\mathrm{AFM}$ 이미지를 통해 각 흡착 단계별로 표면의 변화를 관찰하고 분석하였다. 그 후 생체분자의 길이, 분자 크 기, $\mathrm{R}_{\mathrm{a}}$ (교정된 평면에서부터의 높이차 절대치의 산술 평균), $\mathrm{R}_{\mathrm{ms}}$ (교정된 평면으로부터의 높이차의 평균제곱) 그리고 표면 밀도를 측정하고 값을 확인한 후 비교 분 석하였다.

\section{2. 원자 힘 현미경(AFM)의 측정원리}

원자 힘 현미경(AFM)에서는 주사 탐침 현미경 (scanning tunneling microscope : STM)과는 달리 텅스 텐 또는 백금으로 만들어진 탐침 대신 나노기술로 제 조된 프로브를 사용하였으며 측정 원리는 그림 1과 같 다. 프로브의 모판 끝에 아주 미세한 힘(나노 뉴톤 : nano newton)에서 쉽게 휘어지는 외팔보(캔틸레버 : cantilever) 끝에 원자 몇 개 정도의 크기로 끝이 가공 된 탐침(팁 : tip)을 붙였다. 이 프로브 탐침의 끝을 샘 플 표면에 근접시키면 끌어당기는 또는 밀어 내는 여 러 가지 힘이 샘플표면의 원자와 탐침 끝의 원자사이 에 작용하게 된다. 이 힘에 의해 캔틸레버의 휩이 발생 하고 이 힘이 일정하게 유지되도록 하면서 귀환회로에 의해 정밀 제어하면서 각 지점 $(\mathrm{x}, \mathrm{y})$ 에서 스캐너의 수 직위치를 저장하여 샘플표면의 삼차원 영상을 얻을 수 있는 방법이다. 본 연구에서는 JPK사의 NanoWizard

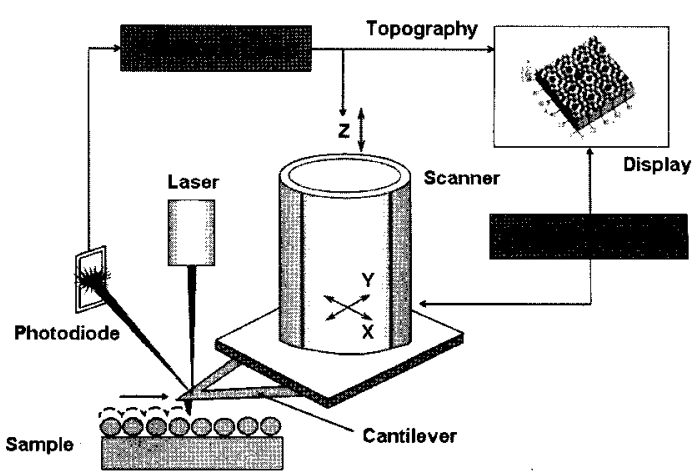

그림 1. $\mathrm{AFM}$ 측정 장치의 모식도

Fig. 1. Schematic diagram of AFM measurement system.

NanoScope AFM을 사용하였고, 안티몬(spring tapping $=0.15 \mathrm{~N} / \mathrm{m}$ )이 도핑된 실리콘 팁과 금으로 코팅된 (spring constant $=0.01 \mathrm{~N} / \mathrm{m}$ ) 실리콘 질소화물(nitride) 캔틸레버 팁을 D.I사에서 구입하였다.

\section{1. 접촉 모드(contact mode)}

접촉 모드는 분리된 포토다이오드 검출기로 캔틸레 버가 편향되는 변화정도를 모니터링하면서 샘플표면에 대해 캔틸레버 끝에 부착된 팁을 주사하여, 귀환회로가 초기에 설정한 편향 값(초기에 설정한 캔틸레버의 휨) 을 유지하도록 하기 위하여 각 $(\mathrm{x}, \mathrm{y})$ 데이터 지점에서 스캐너를 수직으로 움직이면서 캔틸레버가 시료 표면 에 대하여 일정한 편향이 유지되도록 하여, 팁과 샘플 간의 힘이 일정하게 유지하여 항상 팁과 샘플간의 간 격이 쿨롱 힘 대역에서 유지된다. 이때의 힘 $\mathrm{F}$ 는 후크 의 법칙으로부터 $\mathrm{F}$ 는 $-\mathrm{kx}$ 가 된다. 여기서 $\mathrm{F}$ 는 힘, $\mathrm{k}$ 는 스프링상수, $\mathrm{x}$ 는 캔틸레버의 편향이다. 각 지점 $(\mathrm{x}, \mathrm{y})$ 에 서 스캐너의 수직으로 움직이는 거리를 컴퓨터에 저장 하여 샘플표면의 3차원 영상을 얻는 원리인데 이 기술 은 도체뿐 아니라 부도체에도 적용된다.

\section{2. 탭핑 모드(tapping mode)}

탭핑 모드는 보통 $20 \mathrm{~nm}$ 에서 $100 \mathrm{~nm}$ 의 진폭을 가지 고 공진주파수(resonance frequency)근처에서 진동하도 록 캔틸레버의 끝에 부착된 팁을 샘플표면에 대하여 주사한다. 이때 팁은 가볍게 샘폴표면을 두드리는데 진 동의 아래 부분에서 팁은 샘플표면에 접촉 모드와 같 이 접촉된다. 샘플의 높이 변화에 따라 진동 진폭이 변 하게 되고 이 변화는 탑 반대편에 조사된 레이저 빔이 반사될 때에 변화를 초래하게 된다. 이 레이저 빔의 변 화를 포토다이오드 검출기에 의해 검출하여, 검출된 빔 의 진쪽이 초기에 설정한 $\mathrm{R}_{\mathrm{ms}}$ 값을 유지하도록 귀환회 


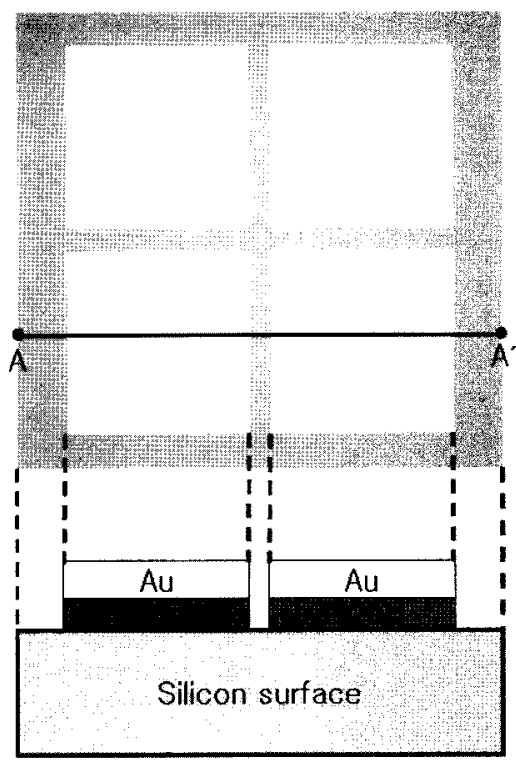

그림 2. Lift-off 기법을 이용한 $\mathrm{Cr} / \mathrm{Au}$ 층 형성

Fig. 2. $\mathrm{Cr} / \mathrm{Au}$ layer formation by using a lift-off method.

로를 사용하여 제어를 하는데 이때 각 지점 $(\mathrm{x}, \mathrm{y})$ 에서 제어된 스캐너의 수직위치를 컴퓨터에 저장하면 샘플 표면의 3차원 영상을 얻을 수 있는 원리이다. 특징은 연질의 시료에 흠을 주지 않고 동시에 수직 해상도를 최고로 할 수 있는 원자 힘 현미경 모드 중 가장 선명 한 영상화가 가능한 모드이다.

\section{3. 실 험}

\section{1. 소자의 제작}

반도체를 기반으로 한 바이오센서로의 적용을 위해 열 증착기(thermal evaporator)를 이용하여 (100) 배열 의 $\mathrm{P}$ 형 실리콘 기판 위에 $\mathrm{Cr}$ 과 $\mathrm{Au}$ 층을 형성하였다. 그림 2는 lift-off 기법을 이용하여 $\mathrm{Cr}$ 과 $\mathrm{Au}$ 층을 형성 시킨 소자의 단면도와 현미경 사진을 보여주고 있다. 먼저 전극 금속인 $\mathrm{Au}$ 와 실리콘의 부착력을 증가시키 기 위해 $\mathrm{Cr}$ 을 약 $200 \AA$ 증착하고 난 후 전극 금속인 $\mathrm{Au}$ 를 약 $500 \AA$ 증착하였다. 이는 실리콘 기반 물질 위 에 $\mathrm{Au}$ 와 싸이올기(thiol, $\mathrm{SH}$ )가 가지는 화학적 결합력 을 이용한 자기조립단분자막(SAM)을 형성하기 위한 것으로 단백질을 포함한 생체관련 물질을 부착하는 방 법으로 가장 적합한 형태로 알려져 있다.

\section{2. 촉정}

측정을 위한 고정화 방법 및 순서는 다음과 같다. 칼

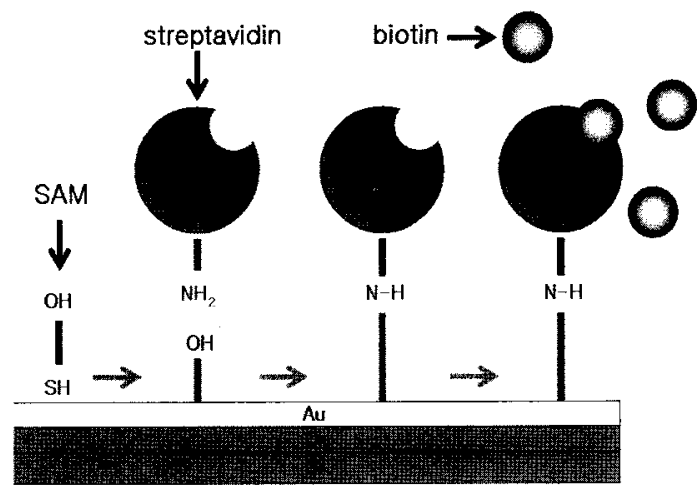

그림 3. 단백질 복합체의 결합에 관한 모식도

Fig. 3. Schematic for binding of protein complexes.

륨 인산 완충 용액 내에 싸이올 용액인 6-mercaptohexanol을 주입하여 자기조립 단분자막을 형성시켰다. 자기 조립 단분자층의 한쪽 끝부분이 Au-SH 막에 부착된 후(-SH)기가 가진 음전하의 영향으로 결합이 형성되어 진다. 그 후 스트렙타비딘 용액을 주입시키고 자기조립 단분자막의 작용기 $(-\mathrm{OH})$ 와 양의 전하를 가지고 있는 스트렙타비딘의 말단 아민기와의 결합을 통해 스트렙 타비딘을 고정시킨다. 동일한 일련의 과정으로 바이오 틴 용액을 주입하고 스트렙타비딘과 바이오틴을 결합 시킨다. 바이오틴은 비타민 B7으로서 2개의 고리구조 가 결합된 화합물이다. 스트렙타비딘과 바이오틴은 매 우 높은 친화력 $\left(\mathrm{Ka} 10^{15} \mathrm{Mol}^{-1}\right)$ 을 가지고 빠른 속도 로 $^{[7,8]}$ 강한 공유결합을 이룬다. 그림 3에 단백질 복합 체의 결합에 관한 모식도를 나타내었다. 이러한 각 물 질들의 성질을 응용하여 측정대상인 감지 물질 위에 $\mathrm{SAM}$, 스트렙타비딘, 바이오틴을 각각 결합시키고 칼 륨 인산 완충용액 내에 $\mathrm{AFM}$ 장비로 단백질 복합체의 흡착여부를 측정하여, 그것의 존재 및 표면 거칠기와 생체물질의 특성을 통해 생체분자의 흡착을 분석하였 다. AFM 이미지는 공기상태에서 탭핑 모드를 사용하 였고 용액상태에서 접촉 모드를 사용하여 $500 \times 500$ $\mathrm{nm}^{2}$ 영역에서 관찰하였다.

\section{4. 결과 및 고찰}

단백질 복합체의 흡착여부를 확인하기 위해 $\mathrm{Au}$, $\mathrm{SAM}$, 스트렙타비딘, 바이오틴 흡착 표면을 공기상태 에서 $500 \times 500 \mathrm{~nm}^{2}$ 영역의 $\mathrm{AFM}$ 이미지로 관찰하여 이를 그림 4에 나타내었다.

단백질 물질의 흡착 단계별 변화를 분석하기 위한 요소들인 길이, 크기, $\mathrm{R}_{\mathrm{a}}, \mathrm{R}_{\mathrm{ms}}$ 및 표면말도를 보다 정확 


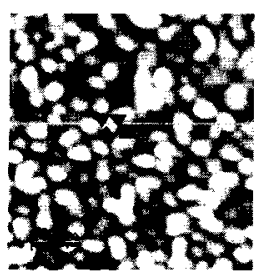

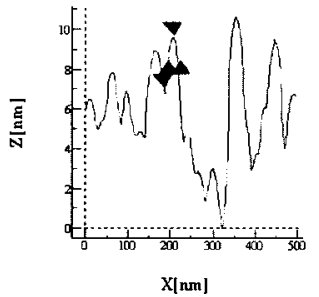

(a)
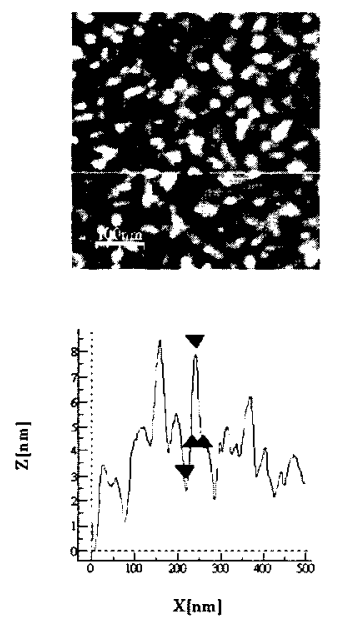

(c)
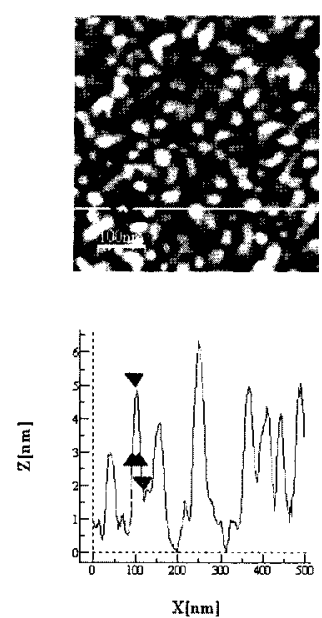

(b)
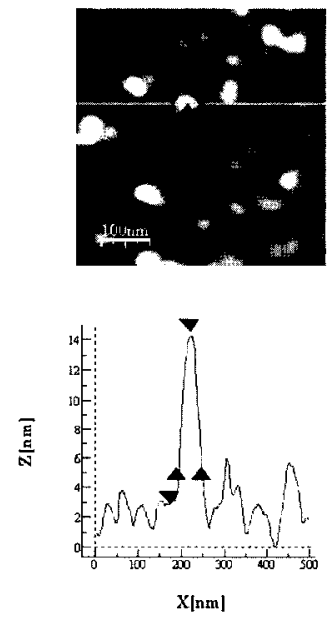

(d)
그림 4. 공기 내 $500 \times 500 \mathrm{~nm}^{2}$ 영역의 $\mathrm{AFM}$ 이미지: (a) $\mathrm{Au}$ (b) SAM (c) 스트렙타비딘 (d) 바이오틴

Fig. 4. AFM image of a $500 \times 500 \mathrm{~nm}^{2}$ area in a air: (a) $\mathrm{Au}$ (b) SAM (c) Streptavidin (d) Biotin.

하게 측정하기 위해서 그림 4(a)와 같이 바탕소자인 $\mathrm{Au}$ 표면을 관찰하였을 때 표면적으로 가장 균일한 면 을 $\mathrm{AFM}$ 이미지 관찰 영역으로 삼았다. 그림 4(b)에 $\mathrm{SAM}$ 이 형성되어진 후의 표면 상태를 관찰한 이미지 를 나타내었다. SAM은 $1 \mathrm{~nm}$ 크기의 단 분자를 형성 하기 때문에 $\mathrm{Au}$ 표면에 흡착하였을 때 $\mathrm{Au}$ 표면인 그 림 4(a)와 비교를 하면 표면적인 상태가 거의 흡사하므 로 그림 4(b)의 이미지를 관찰해 보면 $\mathrm{Au}$ 표면과 거의 변화가 없는 것을 알 수가 있다. 그림 4(c)는 SAM의 말단 수산기와 스트렙타비딘 말단 아민기의 공유결합 으로 형성되어진 스트렙타비딘 포면을 관찰한 이미지
이다. 이를 살펴보면 그림 4(b)와 표면적으로 확연하게 차이나는 것을 알 수가 있다. 기존에 알려진 바와 같이 스트렙타비딘은 $5 \mathrm{~nm}$ 크기와 $60 \mathrm{kD}$ 의 분자량을 ${ }^{[9]}$ 가 지므로 SAM 표면에 흡착되었을 때와는 다른 작은 덩 어리들이 $\mathrm{AFM}$ 이미지에서 스트렙타비딘으로 확인되 어졌다. 그림 4(d)는 스트렙타비딘의 말단 아민기와 바 이오틴의 비타민 B7으로서 2개의 탄소고리 구조로 결 합된 화합물로 형성되어진 바이오틴 표면을 관찰한 이 미지이다. 바이오틴의 경우 단일결합 $(0.154 \mathrm{~nm})$, 벤젠 $(0.140 \mathrm{~nm})$, 이중결합 $(0.134 \mathrm{~nm})$, 삼중결합 $(0.120 \mathrm{~nm})$ 으 로 사슬모양의 고리구조를 가지고 있다. 기존에 알려져 있는 계산식(탄소 14 개의 사슬구조의 길이=탄소길 이 $\times$ 탄소개수)을 바탕으로 우리가 사용한 바이오틴을 대입하여 풀면 $14 \times 0.154=2.156 \mathrm{~nm}$ 이다. 바이오틴은 사슬구조의 고리를 포함하면 길이가 짧아지거나 길어 질 수 있으므로 바이오틴의 길이는 1 3 nm로 예상할 수가 있다. 바이오틴은 단 분자를 형성하므로 스트렙타 비딘 표면에 흡착하였을 때와 다른 이미지를 관찰할 수 있었고, $\mathrm{Au}$ 표면인 그림 4(a)와 바이오틴 상태인 그 림(d)를 비교하면 표면적인 상태가 거의 흡사하다. 그 러나 공기상태에서 바이오틴을 관찰하였을 때 한 덩어 리가 돌출되어서 $\mathrm{AFM}$ 이미지로 측정이 된 것으로 보 아 바이오틴이 여러 층으로 형성되어 가장 윗부분에 측정된 값이 바이오틴인 것으로 확인하였으며 실험결 과 공기상태에서는 결과가 이론과 거의 일치하는 것으

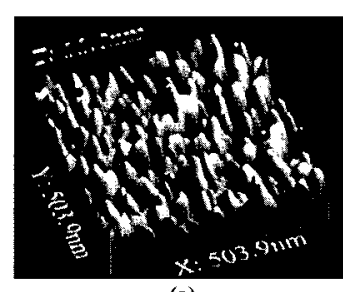

(a)

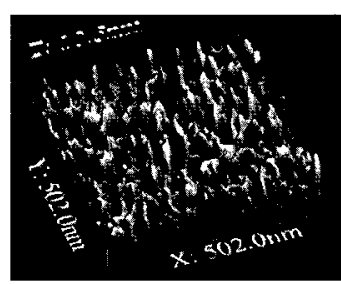

(c)

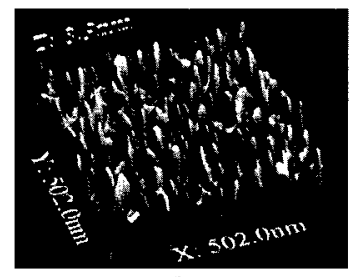

(b)

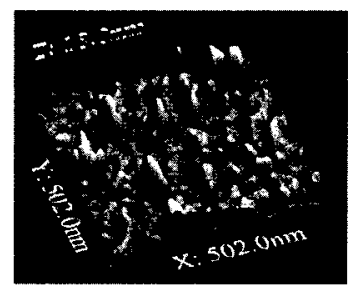

(d)
그림 5. 공기 중의 3차원 바이오 $\mathrm{AFM}$ 사진: (a) $\mathrm{Au}$ 표면 (b) SAM 표면 (c) 스트렙타비딘 표면 (d) 바이오 틴 표면

Fig. 5. The photograph of 3-D Bio-AFM in air: (a) Au surface (b) SAM surface (c) streptavidin surface (d) biotin surface. 
로 확인되었다. 각 단계별로 덩어리 크기의 경향성은 비슷하게 나타났음을 확인할 수 있었다.

그림 5 는 공기 중의 3 차원 바이오 AFM 사진을 나 타내었다.

그림 6은 단백질 복합체의 흡착여부를 확인하기 위 해 $\mathrm{Au}, \mathrm{SAM}$, 스트렙타비딘, 바이오틴 흡착 포면을 용 액 상태에서 $500 \times 500 \mathrm{~nm}^{2}$ 영역의 $\mathrm{AFM}$ 이미지로 관 찰한 사진을 나타내었다. 단백질 센서 개발에 활용 하 기위해서 생체물질인 SAM, 스트렙타비딘 및 바이오턴 을 $\mathrm{AFM}$ 으로 관찰하고 분석하였다. 다소의 오차로 인 해 정확한 분석을 하기에 어려움이 있었다. 용액상태에
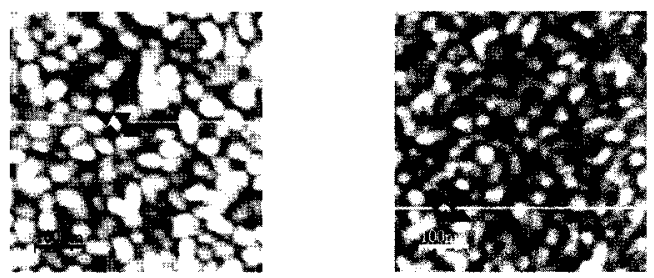

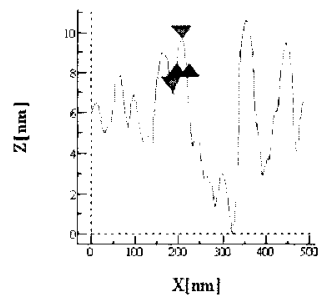

(a)
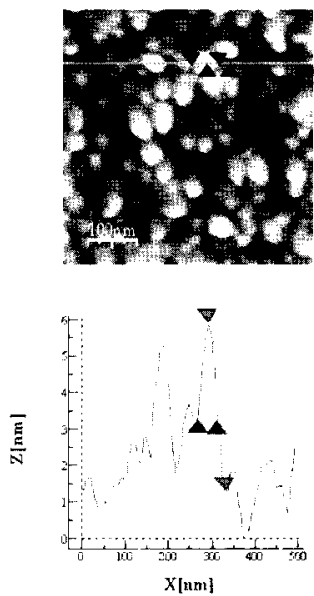

(c)

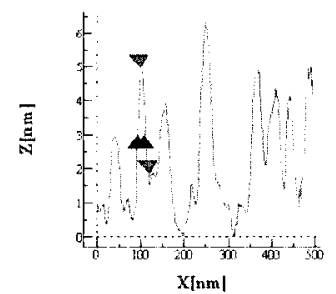

(b)
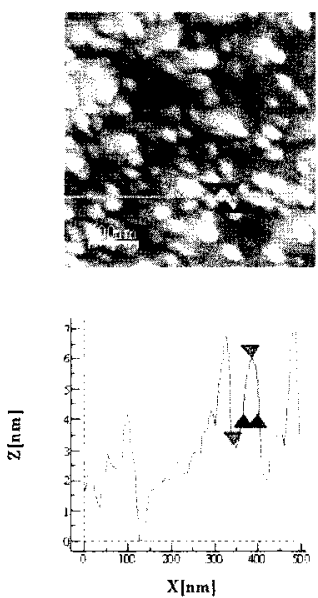

(d)
그림 6. 용액 내 $500 \times 500 \mathrm{~nm}^{2}$ 영역의 $\mathrm{AFM}$ 이디지: (a) $\mathrm{Au}$ (b) SAM (c) 스트렙타비딘 (d) 바이오틴

Fig. 6. AFM image of a $500 \times 500 \mathrm{~nm}^{2}$ area in a solution: (a) Au (b) SAM (c) Streptavidin (d) Biotin.

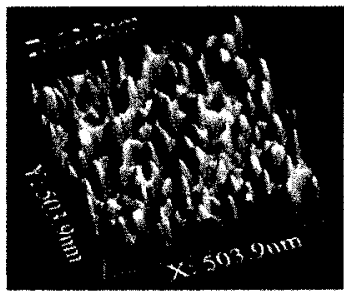

(a)

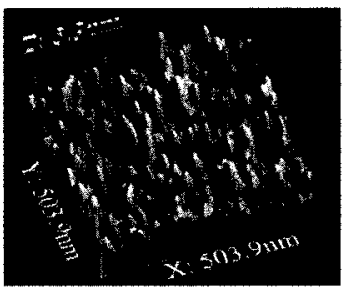

(c)

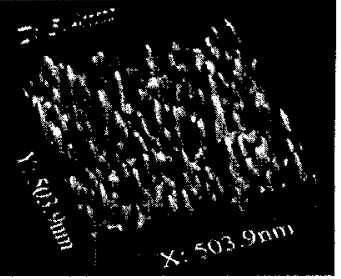

(b)

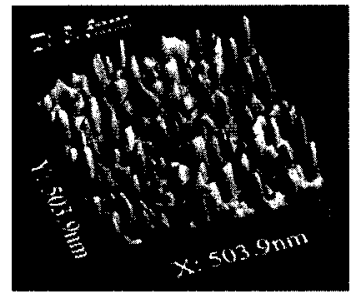

(d)
그림 7. 용액 중의 3차원 바이오 AFM 사진: (a) Au 표면 (b) SAM 표면 (c) 스트렙타비딘 표면 (d) 바이오. 턴 표면

Fig. 7. The photograph of 3-D Bio-AFM in solution: (a) Au surface (b) SAM surface (c) streptavidin surface (d) biotin surface.

서는 결과가 이론과 일치하저 않은 것으로 보아 단백 질 물질이 생체눌질이므로 버퍼에 존제할 때 자기의 성질을 잃어버리그 길이가 길어지거나 짧아지는 현상 을 황인 할 수 있었다. 공기 및 용액상태에서 크기 차 이는 있었지만 경향성은 비슷하게 나타났음을 확인할 수 있었다. 그림 7은 용액 중의 3차원 바이오 AFM 사 진을 나타내었다.

그림 8 은 공기 및 용액상태에서 측정된 $\mathrm{SAM}$ 과 스 트렙타비딘-바이오틴 복합체의 길이 및 크기를 비교한 그래포이다. 공기 및 용액상태에서 Au 표면, SAM 표 면, 스트렙타비딘 포면에서의 경향성은 비슷하게 나타 났다. 공기상태에서 바이오틴을 관찰하였을 때 한 덩어 리가 돌출되어서 $\mathrm{AFM}$ 이미지로 관찰되었다. 측정된 결과로 보아 바이오틴이 여러 층으로 형성되어 가장 윗분분에 측정된 값이 바이오틴인 것으로 학인되었다. 공기 및 용액상태에서 $\mathrm{Au}$ 표면, $\mathrm{SAM}$ 표면, 스트렙타 비딘 표면에서의 넝어리 크기의 경향성은 비슷하게 나 타났다. 전반적으로 공기 및 용액상태에서 $\mathrm{Au}$ 표면, SAM 픈면, 스트렙타비던 픈면, 바이오틴 표면의 길이 가 커짐에 따라 분자 크기가 커짐을 확인하였고, 그 결 과 생체분자의 길이와 크기를 추정할 수 있었다.

그림 9는 공기 및 용액상태에서 측정된 $\mathrm{SAM}$ 과 스 트렙타비딘-바이오틴 복합체의 $\mathrm{R}_{\mathrm{a}}$ 및 $\mathrm{R}_{\mathrm{ms}}$ 비교한 그래 포이다. 실험에서 나온 결과는 다수의 단백질-단백질간 


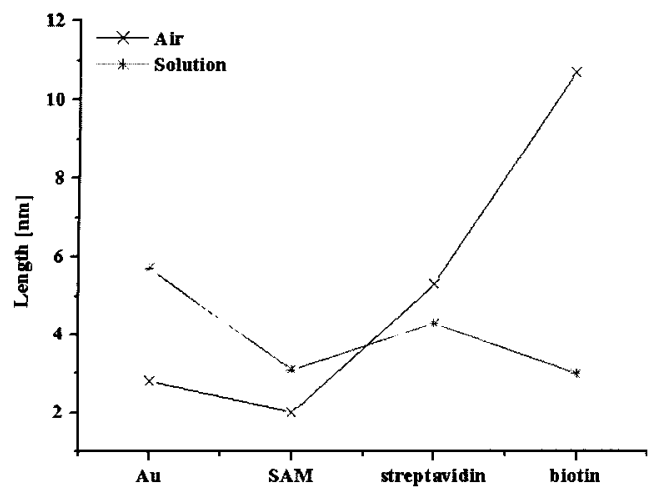

(a)

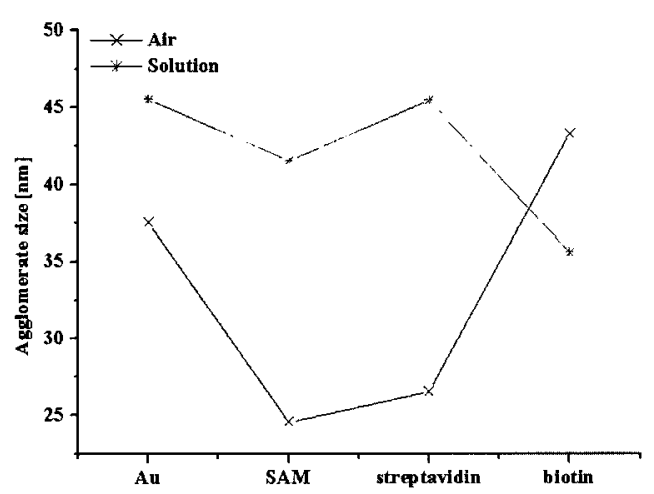

(b)

그림 8. 공기 및 용액상태에서 측정된 SAM과 스트렙타비 딘-바이오틴 복합체의 길이 및 크기 비교: (a) 길 이 비교 (b) 크기 비교

Fig. 8. The length and agglomerate size comparison between SAM and streptavidin-biotin complexes measured in both air and solution: (a) length comparison (b) agglomerate size comparison.

의 결합으로 고리를 형성하여 나타난 값으로 나온 결 과로 예상된다. 분석된 통계적 수치 $\mathrm{R}_{\mathrm{a}}$ 값과 $\mathrm{R}_{\mathrm{ms}}$ 값의 차이가 명확한 것으로 보아 $\mathrm{Au}$ 위에 $\mathrm{SAM}$, 스트렙타비 딘, 바이오틴이 적절하게 흡착된 것으로 판단되고, 평 면으로부터의 높이차를 알 수 있었다.

그림 10 은 공기 및 용액상태에서 측정된 $\mathrm{SAM}$ 과 스 트렙타비딘-바이오틴 복합체의 표면밀도 비교 그래프 를 보여주고 있으며, 표면밀도의 흡착이 적절하게 이루 어진 것으로 판단된다. 공기 및 용액상태에서 $\mathrm{Au}$ 표면, SAM 표면, 스트렙타비딘 포면에서의 표면밀도의 경향 성은 비슷하게 나타났다. 측정단계에서 $\mathrm{Au}, \mathrm{SAM}$, 스 트렙타비딘과 바이오틴의 복합체가 형성되면서 공기 및 용액상태의 $\mathrm{R}_{\mathrm{a}}, \mathrm{R}_{\mathrm{ms}}$ 및 표면밀도의 값이 변하는 것 을 확인할 수 있었다.

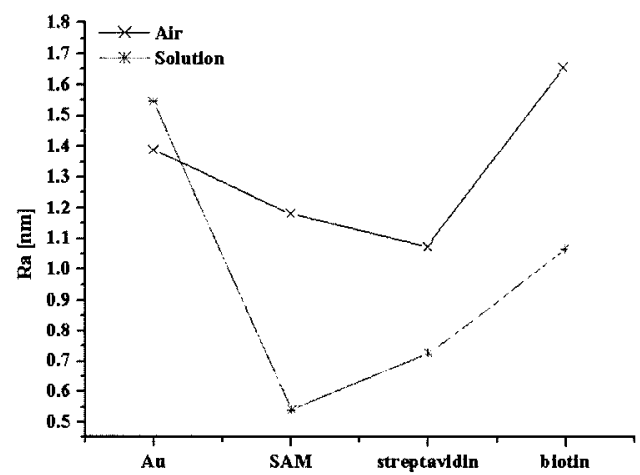

(a)

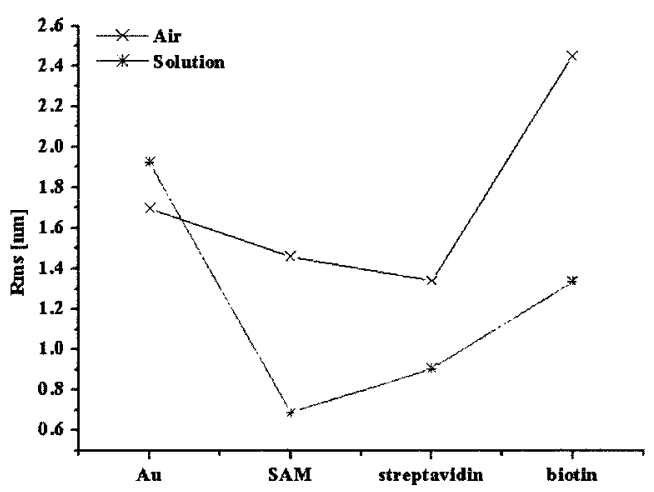

(b)

그림 9. 공기 및 용액상태에서 측정된 $\mathrm{SAM}$ 과 스트렙타비 딘-바이오틴 복합체의 $\mathrm{R}_{\mathrm{a}}$ 및 $\mathrm{R}_{\mathrm{ms}}$ 비교: (a) $\mathrm{R}_{\mathrm{a}}$ 비 교 (b) $\mathrm{R}_{\mathrm{ms}}$ 비교

Fig. 9. The $R_{a}$ and $R_{m s}$ comparison between $S A M$ and streptavidin-biotin complexes measured in both air and solution: (a) $R_{a}$ comparison (b) $R_{m s}$ comparison.

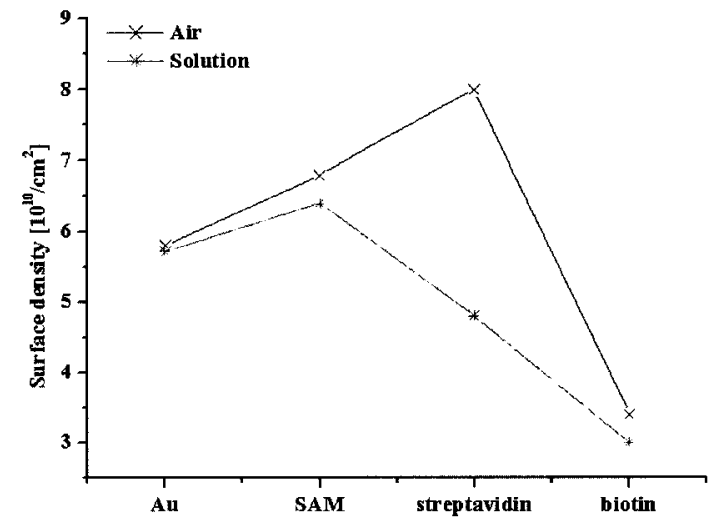

그림 10. 공기 및 용액상태에서 측정된 $\mathrm{SAM}$ 과 스트렙타 비딘-바이오틴 복합체의 표면밀도 비교

Fig. 10. The surface density comparison between SAM and streptavidin-biotin complexes measured in both air and solution. 


\section{5. 결 론}

마이크로 유체공학, 바이오 MEMS(microelectromechanical systems)기술 및 신호처리 기술 등과의 접 목을 통한 스마트 센서 및 Lab-on-a-chip 형태의 단백 질 센서 개발에 활용하기 위해 실리콘 기판 위에 $\mathrm{Cr}$ 과 $\mathrm{Au}$ 를 저항성 열 증착기를 사용하여 각각 $200 \AA, 500 \AA$ 두께를 가지고 순서대로 증착하였다. $\mathrm{Au}$ 위에 자기조 립단분자층을 형성시키고 스트렙타비딘-바이오틴 단백 질 복합체를 홉착시켜 $\mathrm{AFM}$ 을 통해 $\mathrm{Au}$ 표면, $\mathrm{SAM}$ 표 면, 스트렙타비딘 표면, 바이오턴 표면의 상태를 관찰 하였다. 공기 및 용액상태에서 생체분자의 길이, 크기 및 $\mathrm{R}_{\mathrm{a}}, \mathrm{R}_{\mathrm{ms}}$, 표면밀도의 값을 측정하고 그 결과를 분석 하였다. 공기 및 용액 상태에서 $\mathrm{Au}$ 상태, SAM 상태, 스트렙타비딘 상태, 바이오틴 상태의 길이가 커짐에 따 라 분자 크기가 커짐을 확인하였고, 그 결과 생체분자 의 길이와 크기를 추정할 수 있었다. 분석된 통계적 수 치 $\left(\mathrm{R}_{\mathrm{a}}, \mathrm{R}_{\mathrm{ms}}\right.$, 표면밀도)의 차이가 명확한 것으로 보아 $\mathrm{Au}$ 위에 $\mathrm{SAM}$, 스트렙타비딘, 바이오틴의 홉착이 적절 하게 이루어진 것으로 판단되어 진다. 관찰되어진 각 흡착 단계별 변화를 바탕으로 단백질 센서 개발을 위 한 활성물질 조사에 $\mathrm{AFM}$ 이미지를 통한 분석이 적극 활용될 수 있을 것이라 사료된다.

\section{참고 문헌}

[1] H. Y. Lee, H. S. Jung, K. Fujikawa, J. W. Park, J. M. Kim, T. Yukimasa. H. Sugishara, T. Kawai, "New antibody immobilization method via functional liposome layer for specific protein assays",
Biosensors \& Bioelectronics, vol. 7, p. 305, 2005.

[2] 강빈구, 김관선, 김생곤, 김완종, 김우갑, 등영건, 류 재혁, 박원학, 소웅영, 유관희, 이영환, 최원철, 한성 식, "세포생물학", 정문각, p. 119, 1996.

[3] 백경화, “위치 선택적으로 고정화된 단백질 칩 제작”, 연세대학교 석사학위 논문, p. 1, 2002.

[4] C. B. Yuan, A. Chen, P. Kolb, and V. T. Moy, "Energy landscape of streptavidin-biotin complexes measured by atomic force microscopy", Biochemistry, vol. 39, pp. 10219-10223, 2000.

[5] D. Piscevic, W. Knoll, and M. J. Tarlov, "Surface plasmon microscopy of biotin-streptavidin binding reactions on UV-photopatterned alkanthiol selfassembled monolayers", Supramolecular Science, vol. 2, pp. 99-106, 1995.

[6] H. Zhu, M. Bilgin, R. Bangham, D. Hall, A. Casamayor, P. Bertone, N. Lan, R. Jansen, S. Bidlingmaier, T. Houfek, T. Mitchell, P. Miller, R. A. Dean, M. Gerstein, and M. Snyder, "Global analysis of protein activities using proteome chip", Science, vol. 293, pp. 2101-2105, 2001.

[7] 박혜정, 김동선, 한대일, 신장규, 최평, “스트랩타비 딘-바이오틴 단백질 복합체 검출을 위한 PMOSFET 형 바이오센서", 한국센서학회 종합학술대희 논문 집, pp. 151-152, 2003.

[8] 박지은, 김동선, 최호진, 신장규, 김판겸, 임근배, "Bio-AFM 이미지를 이용한 스트렙타비딘-바이오틴 단백질 복합체의 흡착 연구”, 한국센서학회 종합학 술대회 논문집, pp. 342-343, 2005.

[9] M. Losche, M. Piepenstock, D. Vaknin, and J. AlsNielsen, "Molecular recognition processes at functionalized lipid surfaces : A neutron reflectivity study", Thin Solid Films, vol. 4, pp. 659-661, 1992.

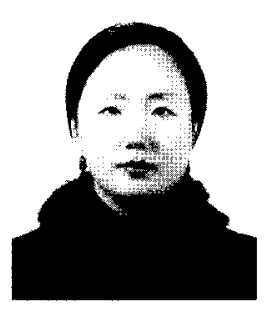

박 지 은

-2004년 경일대학교 전자공학과 졸업 (공학사)

-2004년-현재 경북대학교 대학원 센서 및 디스폴레공학과 석사과정

- 주관심분야 : MOSFET형 반도체 센서, 바이오센서, Bio-MEMS

\section{김 동 선}

- 1999 년 경북대학교 전자공학과 졸업 (공학사)

-2001년 경북대학교 대학원 센서 및 디스 플레이 공학과 졸업(공학석사)

-2001년 현재 경북대학.교 대학원 전자공 학과 박사과정

- 주관심분야 : MOSFET형 반도채 센서, 바이오센서, Bio-MEMS 


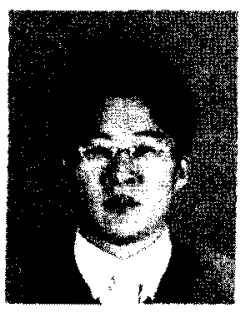

최 호 진

-2005년 경일대학교 전자공학과 졿업 (긍한사)

- 현재 정룩대학그 대학원 전자공학과 셕 샤과정

- 주관심분야 : MOSFET형 반도체 센서, 바이오젠서, Bio-MEMS

\section{깁 판 겹}

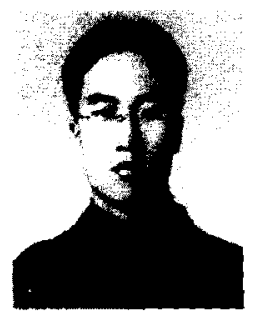

-2001년 UCLA 기계공학과 졸업(공학사) -2003년 포항공과레학료 기계공학과 졿업 (공학석새)

-2003년 현잭 포항공과대학고 기계공학과 박사과정

- 주관심분야 : Bio Sensor, Bio positioning, MOSFET 센서, Micro/Nano Fabrication 기슬

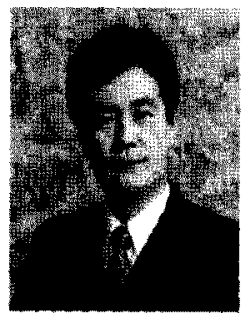

신 장 규

-1978년 서울대학교 전자공학과 졸업 (공학새)

- 1980년 한국과학기술월 전기 및 잔자돔 학가 줄업(공학석사)

- 1991년 미국 률로라도 주립대학교 전기 공학과 좇업(공학박사)

-1995년 1997년 일본 토요하시 기술과학 대학교 교환 교우

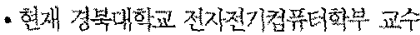

- 주란심분야 : CMOS Image Sensors, Silicon Retina, DNA Sensor, MOSFET Sensor

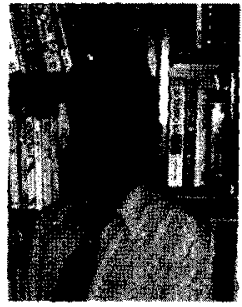

\section{임 근 배}

- 1990션 영남대학교 전자공학과 줄업 (경학사)

-1992년 영남대학교 전자공학과 졸입 (공학석사)

-1996년 일본 둥북대학교 정밀공학과 졸업 (공학박사)

- 1996년 2004년 삼성종합기술원 프로젝 트 咄적

- 현개 포항공과내학고. 기계공ㅇ하곽 조로수 - 죽ㄹㄴ신분야 : Bio Sensor, Micro Reaction 기술, MicroNano Fabrication 기술 